\title{
Det mystiske vinmineral - et forslag til identiteten af vindruekrystallerne
}

Af professor emeritus Svend Erik Rasmussen, Geologisk Institut, Aarhus Universitet

Hermed et forslag til identiteten af de "vindruekrystaller", som omtales i GeologiskNyt 2/05.

Vindruer indeholder, som i øvrigt også andre frugter, en syre kaldet vinsyre samt grundstoffet kalium. Dette danner med vinsyren en forbindelse kaldet kaliumhydrogentartrat, der er bedre kendt under navnet vinsten.

Dette stof er relativt tungt opløseligt. 1 liter koldt vand kan opløse $4 \mathrm{~g}$ vinsten, men ved 100 grader kan denne vandmængde opløse $61 \mathrm{~g}$ af stoffet. Mit gæt er, at der under opkogningen af vindruerne $\mathrm{m}$. $\mathrm{m}$. er sket en vis afdampning af vandet, således at mængden af vinsyre og kalium pr. liter er steget så meget, at der ved afkølingen er udkrystalliseret vinsten.

Navnet kommer af, at der under vingær-

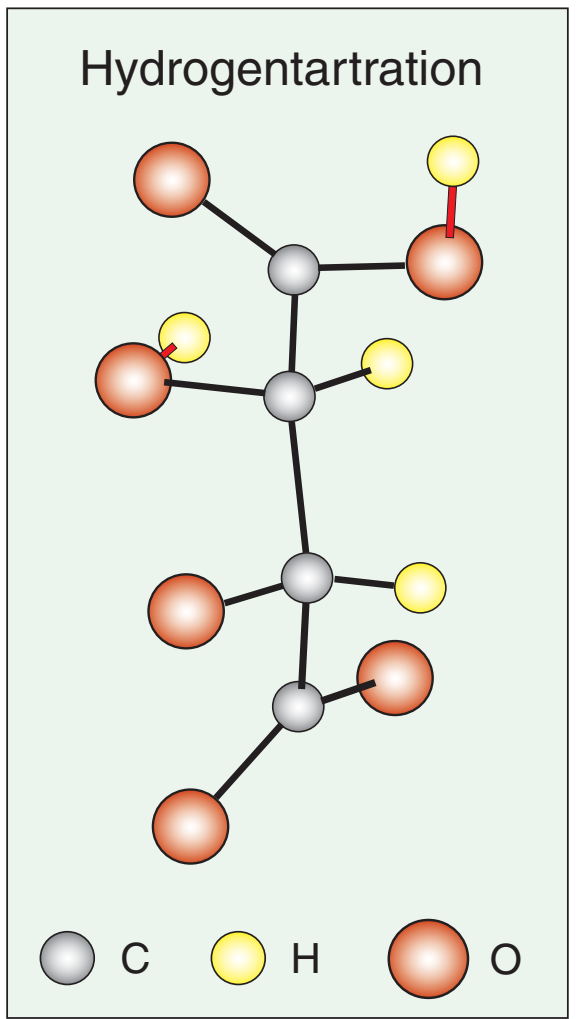

Figuren viser strukturen af en hydrogentartration. Kaliumionen er ikke vist, da den ikke er bundet til én bestemt hydrogentartration, men sammenknytter flere i strukturen. (Grafik: UVH efter forfatterens forlog)

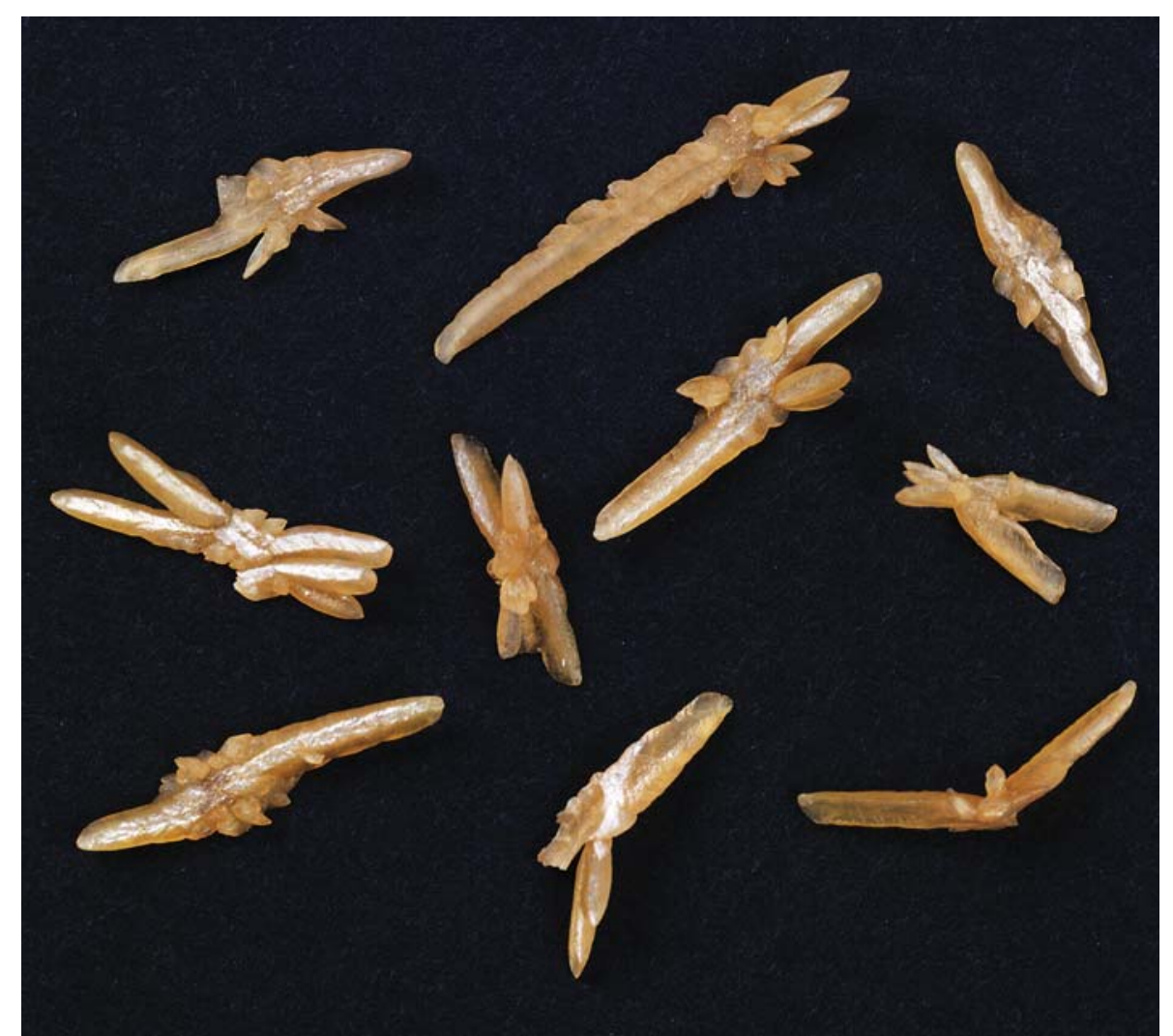

“Vinkrystaller". (Foto: Hans-Henrik Meyer)

ingen dannes alkohol, og vinstenen er langt mindre opløselig i en vand-alkohol-blanding end i rent vand, hvorfor vinstenen udfældes, når alkoholprocenten har nået et vist niveau. Den kemiske formel for vinsten kan skrives som:

\section{HOOCCHOHCHOHCOOK}

I den sammenhæng er det måske værd at minde om, at vinsyren og dens salte spillede en vigtig rolle i etableringen af den videnskab, der kaldes stereokemi.

\section{Pasteur og stereokemien}

Malus havde i 1808 vist, hvordan man kunne polarisere lys, dvs. få lysbølger til at svinge i én bestemt plan ved at lade lyset gå igennem en kalkspatkrystal. Ret hurtigt derefter fandt man, at visse krystaller, fx kvarts, kunne dreje denne polarisationsplan, når lyset gik igennem krystallen. I 1815 opdagede Biot, at ikke alene krystaller af vinsyre, men også opløsninger af denne syre kunne dreje polarisationsplanen, altså måtte det være molekylerne i opløsningen, der besad den egenskab.

Vinsyre danner to natrium-ammoniumsalte, hvoraf det ene er optisk aktivt, dvs. at opløsninger af det drejer polarisationsplanen, medens det andet giver opløsninger uden denne effekt. Louis Pasteur undersøgte i 1848 krystaller af den optisk inaktive form og fandt, at der var to slags krystaller, der var spejlbilleder af hinanden, som højre og venstre hænder er spejlbilleder af hinanden. Han separerede de to typer krystaller fra hinanden ved simpelthen at håndplukke hver form for sig. Han viste derefter, at opløsninger af den ene form drejede polarisationsplanen til højre, som den kendte form for vinsyre gør, og at opløsninger af den anden form drejede polarisationsplanen til venstre. Endvidere viste han, at en opløsning af lige store mængder af de to slags krystaller var optisk inaktiv. Han havde således vist, at molekyler kunne optræde i former, der var spejlbilleder af hinanden. Det blev grundlaget for den senere udvikling af teorien for molekylers rumlige struktur, stereokemien. 